Original Research Paper

\title{
Pelatihan Olimpiade MIPA Bagi Guru dan Peserta Didik SMA Kesuma Mataram
}

\author{
Aris Doyan $^{1 *}$, Susilawati ${ }^{1}$, Harry Soeprianto ${ }^{2}$, Syamsul Bahri ${ }^{3}$ \\ ${ }^{1}$ Program Studi Magister Pendidikan IPA Universitas Mataram \\ ${ }^{2}$ Program Studi Pendidikan Matematika Fakultas Keguruan dan Ilmu Pendidikan, Universitas Mataram \\ ${ }^{3}$ Program Studi Pendidikan Biologi Fakultas Keguruan dan Ilmu Pendidikan, Universitas Mataram
}

\author{
*Corresponding Author: \\ Doyan, Program Studi \\ Magister Pendidikan IPA \\ Universitas Mataram, \\ Indonesia; \\ Email: \\ aris_doyan@unram.ac.id
}

\begin{abstract}
Abstrak: Kegiatan pengabdian pada masyarakat ini secara umum bertujuan untuk mengembangkan kemampuan guru pembina olimpiade dalam mempersiapkan siswa dalam menghadapi olimpiade sains MIPA di tingkat lokal (kabupaten dan provinsi). Untuk mengetahui tingkat kemampuan awal peseta didik yang mengikuti bimbingan olimpiade terlebih dahulu diberikan soal pretest. Berdasarkan skor perolehan pretest, ditemukan bahwa kemampuan peserta didik dalam menyelesaikan soal masih sangat rendah. Hal tersebut disebabkan masih kurangnya bimbingan yang dilakukan oleh guru. Upaya yang dilakukan untuk menyelesaikan permasalahan tersebut adalah dengan memberikan pelatihan kepada guru pembimbing sebanyak lima kali pertemuan untuk masing-masing guru pembimbing bidang studi olimpiade dan mendampingi guru membimbing peserta didik sebanyak lima kali pertemuan. Bimbingan guru olimpiade dilaksanakan oleh dosen ahli pada masing-masing bidang guna untuk mengembangkan kemampuan guru dalam menganalisis silabus, cakupan materi, tipe-tipe soal, dan strategi dalam penyelesaian soal. Pelatihan selanjutnya yang dilakukan adalah kepada siswa yang dilaksanakan oleh masing-masing guru pembina olimpiade dengan didampingi oleh dosen ahli. Kegiatan pelatihan ini dapat dikatan berhasil sebab tingkat partisipasi peserta mencapai $90 \%$ dan peningkatan skor yang diperoleh peserta didik dari skor Post Tes rata-rata memperoleh nilai 70. Berdasarkan hasil wawancara dengan peserta kegiatan diperoleh juga data bahwa kegiatan ini sangat bermanfaat karena telah memberikan pengetahuan dan pengalaman bagi guru pembina olimpiade dan siswa dalam menjawab soal-soal olimpiade MIPA yang variatif.
\end{abstract}

Key words: Pelatihan, olimpiade, MIPA

\section{Pendahuluan}

Olimpiade sains merupakan ajang kompetisi peserta didik yang dilaksanakan tiap tahun baik tingkat kabupaten, provinsi, nasional, dan bahkan internasional. Akan tetapi, permasalahan yang menjadi kendala peserta didik dalam mengikuti olimpiade adalah kurang mampunya mereka dalam menyelesaikan soal-soal olimpiade. Ketidak mampuan peserta didik dalam menjawab, harus secepatnya diatasi dengan cara memberikan bimbingan kepada peserta didik yang memiliki kompetensi dan memiliki semangat yang tinggi untuk mengikuti pembinaan oleh guru Pembina olimpiade. Berdasarkan wawancara dengan guru pembina olimpiade SMAK Kesuma Mataram ditemukan bahwa kemampuan guru dalam menganalisis pola soal olimpiade perlu dilatih untuk dikembangkan. Pengembangan kemampuan guru Pembina olimpiade dapat dikembangkan dengan memberikan pelatihan. Sehingga, dengan pelatihan yang diberikan kepada guru akan dapat meningkatkan kesiapan peserta olimpiade dalam mengikuti olimpiade baik di tingkat kabupaten/kota maupun tingkat provinsi sebab guru Pembina olimpiade telah menguasai trend-trend soal olimpiade yang biasa dilombakan. Mengingat pentingnya pelatihan kepada guru Pembina olimpiade dan peserta didik yang dipersiapkan untuk mengikuti olimpiade, pihak sekolah SMAK Kesuma 
sangat mengharapkan kegiatan pelatihan ini terus dilakukan.

Permasalahan yang dirumuskan adalah bagaimana mengemabngkan kemampuan guru pembina olimpiade dan peserta didik yang dipersiapakan sebagai perwakilan sekolah SMAK Kesuma untuk mengikuti olimpiade MIPA tingkat Kabupaten, Provinsi, dan Nasional.

Kegiatan pelatihan ini bertujuan untuk mengembangkan kemampuan guru dalam menganalisis trend-trend soal olimpiade MIPA pada tingkat Kabupaten, Provinsi, dan Nasional sehingga guru Pembina olimpiade akan membantu peserta didik dalam mempersiapkan dirinya untuk mengikuti olimpiade MIPA. Pelaksanaan pelatihan olimpiade MIPA di SMAK Kesuma Mataram diperoleh manfaatnya oleh peserta pelatihan baik oleh guru pembina olimpiade MIPA dan peserta didik yang dipersiapkan untuk mengikuti olimpiade MIPA.

\section{Metode Pelaksanaan}

Muara dari kegiatan ini adalah untuk meningkatkan penguasaan materi pembinaan olimpiade MIPA SMAK Kesuma Mataram. Terkait dengan hal ini, khalayak sasaran yang strategis dan tepat untuk dilibatkan dalam kegiatan ini adalah masing-masing satu orang guru pembina olimpiade MIPA yang ada di SMAK Kesuma yaitu sebanyak 12 orang guru.

Keterkaitan Kegiatan

Instansi-instansi yang terkait dengan kegiatan ini adalah sebagai berikut.

a. Unit Pelaksana Teknis Dikpora (UPTD) Kota Mataram yang bertanggung jawab langsung terhadap segala kegiatan yang dilakukan oleh SMA Negeri maupun SMA Swasta di Kota Mataram. Kepala UPTD telah menyatakan kesediaannya dalam penugasan guru peserta serta untuk menyediakan tempat dan fasilitas demi berlangsungnya kegiatan.

b. SMAK Kesuma di Kota Mataram, dimana para gurunya mendapat pembinaan langsung dalam kegiatan pengabdian masyarakat ini. Pengetahuan dan keterampilan guru dalam kaitannya dengan pembinaan olimpiade MIPA akan meningkat dan harapannya dapat melakukan pembinaan yang intensif kepada siswa dan akhirnya mampu memperbaiki prestasi siswa-siswi SMAK Kesuma dalam ajang olimpiade MIPA.

c. Universitas Mataram yang merupakan instansi dari tim pengabdian yang menyediakan sumber dana untuk berlangsungnya kegiatan.

Rancangan Evaluasi

Aspek-aspek yang dievaluasi pada kegiatan ini.

a. Aktivitas peserta selama pelatihan berlangsung. Keberhasilan dapat dilihat dari kehadiran dan aktivitas peserta selama kegiatan baik bertanya, menjawab pertanyaan dan berdiskusi. Kegiatan dikatakan berhasil jika minimal $85 \%$ sasaran hadir, dan minimal $85 \%$ peserta yang hadir mengikuti kegiatan secara penuh.

b. Tingkat penguasaan materi. Keberhasilannya dilihat dari skor perolehan pada Post Tes, yaitu berhasil jika tergolong tuntas yaitu rata-rata skor post tes minimal 70 dengan minimal $85 \%$ peserta skornya lebih dari 70 .

\section{Hasil dan Pembahasan}

Kegiatan pelatihan olimpiade MIPA telah dilaksanakan di SMAK Kesuma Mataram. Pelatihan olimpiade MIPA meliputi Fisika, Matematika, Biologi, dan Kimia. Sasaran pelatihan olimpiade adalah guru fisika, matematika, biologi, dan kimia. Guru yang telah dibimbing oleh dosen didampingi oleh dosen untuk melatih siswa.

Pelatihan Olimpiade MIPA ini berlangsung selama lima minggu, yakni dari minggu pertama Maret 2018 sampai Juli 2018. Pembinaan dilaksanakan setiap hari sabtu. Pelatihan guru pembinas olimpiade setiap bidang studi dilakukan masing-masing lima kali pelatihan khusus kepada guru dan pendapingan guru pembimbing dalam membimbing siswa dilaksanakan lima kali untuk setiap mata pelajaran, sehingga, jumlah total ada 40 kali pembinaan. Setiap pembinaan berlangsung dari pukul 14.00 sampai dengan 18.00 wita.

Narasumber dalam kegiatan Pembinaan Olimpiade di SMAK Mataram adalah

1. Drs. Aris Doyan, M.Si., Ph.D. dan Dra. Susilawati, M.Si., Ph.D (bidang Fisika)

2. Dr. Harry Soeprianto, M.Si. (bidang Matematika)

3. Dr. Drs. Syamsul Bahri, M.Si (bidang Biologi)

4. Asnah, M. Pd (bidang Kimia)

Peserta kegiatan Pembinaan Olimpiade MIPA di SMAK Mataram adalah sejumlah 4 orang guru, 
yakni 1 guru fisika, 1 guru matematika, 1 guru biologi, dan 1 guru kimia,. Untuk siswa ada 55 orang yaitu 6 siswa fisika, 20 siswa biologi, 11 siswa fisika dan 18 siswa matematika yang kesemuanya berasal dari kelas X danXI yang berpotensi untuk dapat lolos dalam kompetisi Olimpiade terutama mata pelajaran Fisika, Kimia, Biologi dan Matematika tahun 2018/2019. Oleh karena itu, siswa-siswa yang mengikuti pembinaan inimestinya memiliki kemampuan akademik yang unggul (lebih baik) dari pada siswa-siswa yang lainnya, terutama dalam mata pelajaran MIPA.

Bentuk kegiatan Pembinaan Olimpiade MIPA di SMAK Kesuma Mataram adalah pertemuan berbentuk tambahan pelajaran. Pertemuan dilakukan sekali dalam seminggu. Pertemuan berlangsung selama empat jam. Dalam tiap jam diberikan latihanlatihan soal MIPA, khususnya soal-soal yang setingkat Olimpiade Nasional. Soal-soal seperti ini bukanlah soal-soal yang biasa ditemukan untuk ujian semesteran maupun ujian akhir. Soal-soal Olimpiade tingkat SMA/SMK justru hampir menyamai soalsoalsetingkat mahasiswa di perguruan tinggi.

Proses bimbingan olimpiade fisika di SMAK Kesuma berjalan baik dan kondusif, akan tetapi ada beberapa point penting yang dapat disimpulkan dari bimbingan antara lain:

1. Penguasaan konsep fisika peserta bimbingan masih kurang, hal ini terlihat pada hari pertama pemberian pre-test yang berisi soal-soal fisika dasar, peserta didik terlihat kesulitan menjawab soal-soal tersebut.

2. Peserta didik belum terbiasa dengan soal-soal HOTS hal ini ditunjukkan pada saat bimbingan hari kedua dan ketiga ketika saya mulai menyisipkan soal olimpiade pada saat bimbingan, peserta terlihat kebingungan dan sangat kesulitan, akan tetapi hal positifnya adalah peserta tetap antusias untuk mencoba memecahkan soal-soal tersebut. Untuk merespon hal itu, saya mencoba mengajarkan cara memecahkan soal-soal tersebut secara bertahap sambil menguatkan konsep dasar dan tampaknya peserta bimbingan mulai mendapat gambaran tentang soal-soal tipe olimpiade fisika serta bagaimana alur untuk memecahkannya.

3. Pemberian post-test test dihari terakhir berlangsung lancar meskipun waktu yang diberikan cukup singkat, tetapi peserta terlihat sudah mampu mengerti maksud soal dan menemukan formula untuk memecahkannya, hal ini tampak dari nilai post-test yang mengalami peningkatan dari beberapa peserta bimbingan.

Sama halnya dengan pelaksanaan pelatihan olimpiade matematika, biologi, dan kimia yang telah dilakukan berjalan dengan lancar dan sesuai dengan yang diharapkan. Sebab tingkat partisipasi dan peningkatan kemampuan siswa lebih dari $85 \%$.

Secara umum, pelaksanaan kegiatan Pembinaan Olimpiade MIPA berjalan dengan baik. Sebagaimana disebutkan di atas pelaksanaan pembinaan ini dilaksanakan dalam bentuk tambahan pelajaran yang berlangsung selama 4 jam, dimulai jam $14.00 \mathrm{~s} / \mathrm{d}$ 18.00. Jadwal ini setelah jadwal mata pelajaran reguler. Tiap pertemuan diisi dengan berbagai latihan soal MIPA terutama soal-soal ditingkat Olimpiade. Pertama, setiap siswa diminta untuk mengerjakan berbagaisoal-soal Olimpiade secara mandiri maupun bekerjasama dengan teman sebangku. Hal ini dilakukan selama kurang lebih 60 menit. Dalam setiappertemuan diusahakan agar siswa-siswa tersebut dapat mengerjakan tiga sampai lima soal-soal Olimpiade MIPA. Kedua, narasumber (pembina) membahas satu sampai dua soal. Untuk membahas satu buah soal Olimpiade MIPA tidaklah sederhana karena memang tingkatannya tinggi. Satu soal membutuhkan sekitar tiga puluh menit untuk dibahas dengan baik. Pembahasan soal menjadi penting sekali agar siswa-siswa menjadi paham untuk mengerjakan soal-soal lain yang sejenis. Salah satu indikator yang penting dalam kompetisi Olimpiade MIPA adalah terbiasa mengerjakan soalsoal setingkat Perguruan tinggi. Salah satu tujuan pembinaan ini adalah untuk membiasakan siswasiswa dengan soal Olimpiade. Selain itu, tujuan lain dari pembinaan ini adalah menumbuhkan intuisi agar siswa dapat beradaptasi dengan cepat dengan berbagai soal yang berbeda.Selama pembinaan berlangsung, respon dari siswa cukup baik. Siswa bersemangat dalam mengikuti setiap pembinaan. Siswa sangat aktif mengerjakan soal-soal Olimpiade yang diberikan oleh pembina. Banyak pula pertanyaan-pertanyaan yang diajukan oleh siswa baik ketika mengerjakan soal-soal maupun ketika pembina memberi penjelasan tentang soal tertentu. Respon dari guru-guru juga cukup baik. Guru-guru sangat mendukung adanya pembinaan ini, terutama dalam hal mensukseskan tiap-tiap pertemuan. Guru juga menentukan ruang mana yang dapat digunakan untuk pembinaan. Pada akhirnya, tidak semua siswa 
yang mengikuti pembinaan ini akan diajukan untuk mengikuti kompetisi Olimpiade MIPA. Selama peimbinaan ini terjadi pula proses seleksi.

Hasil terbaik dari kegiatan pembinaan Olimpiade MIPA ini adalahmeningkatnya minat belajar pada siswa-siswa yang mengikuti pelatihan, terutama pada bidang MIPA.

Secara umum tidak terjadi hambatan yang berarti dalam keseluruhan kegiatan ini, hanya saja ada hambatan kecil berupa tidak lengkapnya jumlah siswa yang datang.

\section{Kesimpulan dan Saran}

Kegiatan pelatihan ini sangat bermanfaat bagi guru pembina olimpiade MIPA dan bagi peserta didik yang dipersiapkan untuk mengikuti kegiatan olimpiade. Keberhasilan kegiatan ini dapat dilihat dari tingkat antusias guru dan siswa dalam mengikuti pelatihan. Tingkat kehadiran peserta mencapai $90 \%$ dan peningkatan kemampuan siswa dalam mennyelesaikan soal olimpiade meningkat dilihat dari perolehan skor post test rata-rata siswa memperoleh skor 70 dari skor menggunakan skala 100.

\section{Ucapan Terimakasih}

Terima kasih banyak kepada departemen pendidikan penelitian dan teknologi untuk pengabdian kepada masyarakat tahun 2018 dibiayai dari sumber dana DIPA BLU universitas Mataram surat perjanjian nomor 1299/UN18/LPPM/2108. Terima kasih banyak kepada pimpinan sekolah mitra, guru pembina olimpiade dan peserta didik SMAK Kesuma Mataram yang telah mengikuti kegiatan pelatiahan dengan antusias. dan semua pihak yang telah membantu untuk terlaksananya kegiatan pengabdian ini.

\section{Daftar Pustaka}

Anonim. 1991. Kamus Besar Bahasa Indonesia Edisi II. Jakarta : Balai Pustaka 2005. Kisi-kisi Olimpiade Sains Tingkat SMA. Jakarta: Depdiknas
Supriyadi. 2007. Kurikulum Sains dalam Proses Pembelajaran Sains. Yogyakarta: Pustaka Tempel Sari. 